\title{
ОСВІТНЯ ТРАНСФОРМАЦІЯ ЛЬВІВСЬКОЇ ЄЗУЇТСЬКОЇ ШКОЛИ В 1660-Х РР.: МІФИ І РЕАЛЬНІСТЬ
}

\author{
С. О. Серяков
}

Ссряков С. О. Освітня трансформація Львівської єзуїтської школи в 1660-х рр.: міфи і реальність. В статті розглядаються передумови, перебіг і наслідки першої спроби створення Львівської академії. Проаналізувавши рівень матеріального забезпечення і структуру освітньої діяльності відповідного осідку ордену, автор підважує історіографічний міф про те, що вся попередня історія Львівського колегіуму була невпинним й послідовним рухом до набуття ним університетського статусу. Насправді освітня трансформація 1661 р. стала результатом дії низки ситуативних чинників тодішнього суспільно-політичного життя. Поява фундаційного диплома Яна Казимира не гарантувала втім кінцевого успіху - внаслідок протидії Краківської академії Львівська академія так і не набула легітимного статусу. Водночас рівень їі структурного розвитку і матеріального забезпечення швидко перестали відповідати університетським амбіціям львівських єзуїтів.

Ключові слова: Львівська академія; фундаційний диплом Яна Казимира; єзуїтська школа; Річ Посполита.

Серяков С. О. Образовательная трансформация Львовской иезуитской школы в 1660-х гг.: мифы и реальность. В статье рассматриваются предпосылки, ход и последствия первой попытки создания Львовской академии. Проанализировав материальное обеспечение и структуру образовательной деятельности соответствующего дома ордена, автор подвергает сомнению историографический миф о том, что вся предыдущая история Львовского коллегиума была непрестанным и последовательным движением к приобретению университетского статуса. В действительности образовательная трансформация 1661 г. была предопределена рядом ситуативных факторов тогдашней общественно-политической жизни. Появление фундационного диплома Яна Казимира не гарантировало однако конечного успеха - вследствие противодействия Краковской академии Львовская академия так и не приобрела легитимного статуса. В то же время уровень ее структурного развития и материального обеспечения быстро перестали отвечать университетским амбициям львовских иезуитов.

Ключевые слова: Львовская академия; фундационный диплом Яна Казимира; иезуитская школа; Речь Посполитая.

Seryakov S. O. An Educational Transformation of Lviv Jesuit School in 1660s: Myths and Reality. The article deals with the prerequisites, sequense and consequences of the first attempt of the Lviv academy's establishment. Analysing the structure of Lviv Jesuit school and the level of income, an author combats a historiography myth that all previous history of Lviv College was incessant and successive motion to getting the university status. This educational transformation was defined by several factors of then social and political life. The appearance of John II Casimir's foundational diploma however hadn't guaranteed the success - the counteraction of the Cracow academy resulted in the lack of the legitimate status of the Lviv academy. Meanwhile the level of its structural development and material providing quickly became uncompatible with the university ambitions of the Lviv jesuits.

Keywords: Lviv academy; the John II Casimir's foundational diploma, Jesuit school, Polish-Lithuanian Commonwealth.

Товариство Ісуса відіграло важливу роль у культурному розвитку України. Організаційна і концептуальна єдність його шкільництва забезпечила масове та системне поширення на українських землях гуманістичного канону освіченості, який передбачав добре знання класичних мов (i, насамперед, латини), володіння риторичними вміннями і широку обізнаність із античною спадщиною. Водночас єзуїтське шкільництво стало тим подразником, який запустив механізм модернізації у православній освіті. Цей процес завершився постанням навчальних закладів нового типу (Острозької академії, братських шкіл, Києво-Могилянського колегіуму), які в різній мірі враховували елементи шкільної моделі Товариства Ісуса.

Є втім ще один вкрай важливий суспільний вимір діяльності єзуїтів на ниві освіти. Адже припиняючи свою історію в 1773 р., їх осередки стали базою (кадровою, матеріаль- 
ною еtс.) для виникнення нового покоління шкіл (під орудою тієї ж Комісії Едукації Народової), які забезпечили трансфер освітніх традицій від ранньомодерної до модерної доби. Це дає підстави багатьом сучасним навчальним закладам вести свій родовід від єзуїтських шкіл XVI-XVIII ст. Але якщо у випадку Вільнюського університету наголошення на його заснуванні у 1579 р. є виправданим, то ситуація з Львівським університетом виглядає набагато складнішою і заплутанішою. В даному випадку йдеться не тільки про дискретність існування вищого навчального закладу у Львові (між закриттям єзуїтської школи в 1773 р. і відкриттям Йосифінського університету в 1784 р. немає проміжної освітньою ланки), але й про сумнівну легітимність самої освітньої трансформації 1661 p.

Звідки ж взялася легенда про те, що саме ця дата $є$ відправною точкою історії Львівського університету (а саме так вона позиціонується на офіційному сайті вишу ${ }^{1}$ Я Якими були насправді юридичні наслідки появи диплому Яна Казимира і чи відповідали реалії у Львівській школі ордену омріяному нею академічному статусу? Відповіді на ці питання я спробую дати в своїй статті.

Слід сказати, що т. зв. історія Львівської академії (тобто - сукупність подій, пов’язаних iз появою диплома Яна Казимира 1661 р.) здавна цікавила польських авторів ${ }^{2}$. Але перша наукова рефлексія 3 цього приводу (а не просто констатація самого факту구을 постає наприкінці 1820-х pp. Ігнаці Ходиніцький накреслив той сюжетний ескіз історії Львівської академії, який згодом активно наповнювали джерельним і фактографічним матеріалом польські автори аж до кінця XIX ст. Зокрема, йдеться про обставини появи фундаційного диплома Яна Казимира, його оскарження на екстраординарному сеймі 1662 р. (Краківською академією і земськими послами), перебіг вирішення справи у римській курії. Підсумовуючи, цей польський автор виносить чіткий вердикт: Львівської академії так і не було створено, оскільки Сейм мав обов'язково затвердити рішення короля, а він цього не зробив ${ }^{4}$.

У добу Романтизму, коли створюється “чорний образ” Товариства Ісуса, його головні конструктори (Адріан Кжижановський, Юзеф Лукашевіч і ін.) додають до сюжету I. Ходиніцького нових барв і тематичних нюансів. Історія освітньої трансформації 1661 р. розглядається ними як епізод масштабної гри, яка ведеться між єзуїтами і Краківською академією на великій шахівниці Речі Посполитої (а її ключовими пунктами є Краків, Познань, Вільно і Львів). Приділення особливої уваги цьому конфліктові у працях польських авторів кінця 1830-х - початку 1850-х рр. пояснюється тим, що саме тоді конструюється образ ранньомодерної Краківської академії як головного осередку польської освіти, культури i науки. Вона a priori протиставляється космополітичній і обскурантистській єзуїтській освітній моделі. В “Історії шкіл” Юзефа Лукашевіча вперше звучить той мотив створення Львівської академії, який згодом стане канонічним. А саме - що це був превентивний крок, спрямований на те, аби унеможливити виникнення у Львові православного університету5. Ю. Лукашевіч і А. Кжижановський чітко наголошують на неправомочності королівського диплому 1661 р. (адже він не був схвалений Сеймом), демонструють несприйняття соціальною елітою Речі Посполитої ідеї Львівської академії і вважають цю справу вирішеною вже після сеймової ухвали 1662 р. ${ }^{6}$. Аби посилити свою думку про нелегітимність Львівської академії, Ю. Лукашевіч наголошує на тому, що єзуїти задля досягнення позитивного вердикту римського папи, вдалися до відвертого шахрайства (видали звернення, підписане низкою лобістів їхніх інтересів, за волю всієї соціальної еліти Речі Посполитої) ${ }^{7}$.

Такі уявлення про освітню трансформацію 1661 р. збережуться в польській історіографії майже в незмінному вигляді до кінця XIX ст., коли до неї внесуть суттєві зміни о. Станіслав Заленський, Людвік Фінкель і Станіслав Яворський ${ }^{8}$. Перший із них пояснює невдачу єзуїтів у вирішенні справи Львівської академії на сеймах 1661 і 1662 рр. підступними інтригами Краківської академії. Саме остання підбурювала шляхту (через цілеспрямовану роботу на воєводських сеймиках, поширення агітаційної літератури тощо) вносити протестації проти заснування Львівської академії, провокували виступати проти неї представників львівського магістрату і духовенства. Формально справу академії було програно, але фактично вона діяла - читалися теологічні курси, присуджувалися наукові ступені тощо?. Сплеск уваги у польській історіографії кінця XIX - початку XX ст. до справи Львівської академії (в цьому контексті насамперед слід згадати про твори Л. Фінкеля і С. Яворського) відбивав тодішні прагнення поляків закріпити за собою Львівський університет (як і 
в цілому панівні позиції в Галичині), обгрунтувавши його споконвічну польськість. Для цього, звісно ж, треба було довести легітимність освітньої трансформації 1661 р. 3 цією метою Л. Фінкель опублікував фундаційний диплом Яна Казимира, аргументовано довів його автентичність, а також - зобразив його логічним підсумком поступального розвитку освітньої діяльності Львівського колегіуму за попередні півстоліття ${ }^{10}$. Польський історик не сумнівався у легітимності новоствореного Львівського університету, який згодом став “твердинею католицької латинської цивілізації проти схизми і східної візантійщини”" . Ця теза досить промовисто ілюструє справжні інспірації появи праці Л. Фінкеля, яка цілком вписується у тодішній дискурс українсько-польського протистояння і контекст міжнародних відносин напередодні Першої світової війни.

У міжвоєнну добу думка про те, що починаючи з 1661 р. у Львові існувала академія, стає по суті аксіомою. Саме такий безапеляційний висновок робить Станіслав Кот, загалом неприхильний до Товариства Ісуса ${ }^{12}$. За часів ПНР дослідники єзуїтської тематики уникали львівських сюжетів, географічно пов'язаних у той час вже не з Польщею, а 3 “братерським" СРСР. Але в 1990-х рр. неоромантичний образ польської Львівської академії набуває нібито другого дихання ${ }^{13}$. Такі ж однозначні висновки зустрічаємо в українській радянській історіографії, в якій диплом Яна Казимира вважається відправною точкою історії Львівського університету ${ }^{14}$.

Перш ніж проаналізувати перебіг, юридичне підгрунтя і реальні наслідки освітньої трансформації 1661 р., спробуємо з'ясувати, наскільки вона взагалі була логічною на тлі попередньої історії шкільної діяльності єзуїтів у Львові. Чи дійсно існували передумови для створення тут вищого навчального закладу?

Львівська єзуїтська школа почала діяти восени 1608 р. у складі класів граматики і поезії, а також курсу моральної теології. Через рік до них додається риторика, в 1611 р. починається викладання логіки, а в 1613 р. - також математики і фізики ${ }^{15}$. Така складна структура освіти (повний цикл дисциплін studia inferiora, доповнений дворічним курсом філософії і моральною теологією) напередодні Хмельниччини існувала лише в трьох єзуїтських осідках на українських землях Речі Посполитої (окрім Львова, це були Острог і Вінниця $)^{16}$. Отже, в регіональному масштабі Львівська школа ордену була однією із найкращих, але в межах Польської провінції Товариства Ісуса вона належала до середняків. Адже за ступенем свого структурного розвитку і освітнім значенням Львівський колегіум поступався таким визнаним осередкам єзуїтського шкільництва як Каліш, Краків (в період до 1634 р.), Люблін чи Познань ${ }^{17}$.

Паралельно з розвитком структури освіти, зростало й число вихованців Львівської єзуїтської школи. В 1609 р. тут навчалося 400, в 1613 р. - 550, а в 1615 р. - вже 600 юнаків $^{18}$. Цей показник, досить вражаючий за регіональними мірками ${ }^{19}$, однак виглядає непереконливо на тлі того ж Познанського колегіуму. В 1610 р. - тобто напередодні аналогічної освітньої трансформації - в ньому нараховувалося 1200 учнів ${ }^{20}$.

Важливою передумовою структурного розвитку єзуїтських осередків було зростання рівня їх достатку. Без цього не можна було мріяти ані про заснування певної школи, ані про здійснення наступних кроків на шляху її структурної розбудови, включно з переходом на університетський рівень. У цьому відношенні Львівський колегіум до 1648 р. також аж ніяк не демонстрував великих амбіцій. Безперечно, рівень його добробуту був вищим, порівняно із більшістю інших осередків ордену на сході Польської провінції. Скажімо, щорічні прибутки Львівського колегіуму в 1648 р. склали 10000 фл., тоді як Вінницький єзуїтський осередок отримав того року 3400 фл., Переяславський - 4000 фл., Кросненський - 4050 фл., Барський - 4500 фл., Луцький - 7110 фл. ${ }^{21}$. Але цей показник аж ніяк не був рекордним для регіону. Скажімо, Острозький і Ярославський колегіуми у 1645 р. отримали відповідно 21000 та 17514 фл. ${ }^{22}$. Хоча відповідних даних щодо 1648 р. й бракує, але, зважаючи на відсутність за це триріччя очевидних деструктивних чинників у розвитку вищезгаданих осідків Товариства Ісуса, рівень їх добробуту ймовірно лишався приблизно на тому ж самому рівні.

1648 рік природно призвів до погіршення становища Львівського колегіуму. Однак його не можна вважати настільки ж критичним, як у випадку більшості інших осідків ордену в Україні. Львів не перебував на теренах, підконтрольних Війську Запорозькому (з неминучим в такому разі припиненням діяльності єзуїтського осередку); міська інфра- 
структура колегіуму не була пошкодженою, а заміські маєтки зазнавали лише ситуативних спустошень - як, скажімо, восени 1648 р. Не дивно, що в 1649/50 р. Львівський осідок Товариства Ісуса отримав сумарні прибутки у розмірі 12098 фл., що більш, ніж на 20\%, перевищувало аналогічний показник мирного літа 1648 р. Поширення епідемії чуми в 1651 р. безумовно нанесло шкоду економічному потенціалові колегіуму (й примусило єзуїтів тимчасово закрити школу), але критичного удару по його функціонуванню не завдало. В цьому пересвідчує динаміка зміни щорічних прибутків Львівського осередку ордену (1650/51 p. - 8538 фл., 1651/52 р. - 6180 фл., 1652/53 р. - 8726 фл., 1653/54 р. - 12212 фл., $1654 / 55$ р. - 8515 фл.), яка говорить про швидке відновлення ним своїх господарських кондицій. Останне дозволило не лише зберегти у Львові існуючу структуру освіти, але й розширити іï за рахунок курсів моральної теології (з 1649/50н. р.), екзегези Св. Письма, схоластичної і контроверсійної теології (з 1653/54н.р. $)^{23}$. Ці нововведення суттєво підвищували освітній статус Львівської єзуїтської школи і водночас - вперше засвідчили iii університетські амбіції. Адже перераховані вище чотири дисципліни складали предметне ядро теологічного факультету в тих університетах, які перебували під контролем Товариства Ісуса. Зокрема, саме так було у Вільно, де, щоправда, існував ширший пакет теологічних студій, який включав також гебрайську мову ${ }^{24}$. Доба Потопу, коли Галичина перетворилася на арену військових дій різних армій (Війська Запорозького, московітів, поляків, трансильванців, шведів) природно загальмувала процес реалізації цих намірів. В 1656-1660рр. Львівський колегіум не отримав зі своїх сільських маєтків - внаслідок їх спустошення - жодних коштів, тоді як у трохи кращому 1654/55 р. до нього надійшло звідти лише 3031 фл. За таких умов простежується природне спрощення структури освіти, 3 якої зникають майже всі нововведення, а саме - курси схоластичної і контроверсійної теології, а також екзегези Св. Письма (з 1657/58 н. р. $)^{25}$.

І ось в цей - з об'єктивної точки зору - цілком несприятливий момент львівські єзуїти чомусь переходять до реалізації своїх університетських планів. Що ж примусило Товариство Ісуса прискорити якісну трансформацію своєї Львівської школи, не чекаючи покращення внутрішньополітичного становища в Речі Посполитій і відновлення господарчого потенціалу відповідного осередку ордену? Самі тодішні єзуїти трактували цей поспіх як превентивний удар, покликаний не допустити відкриття у Львові православної академії. Власне на цьому й наголошувалося у пропозиції Конгрегації Польської провінції, яку було схвалено 8 жовтня 1660 р. Зокрема, зазначалося, що “нинішня ситуація $є$ сприятливою для того, аби насамперед випередити схизматиків, які мають тверді наміри заснувати в цьому місті університет (universales scholas)"26. Можливість створення у Львові православної академії теоретично передбачалася Гадяцькою угодою. Остання санкціонувала не лише підвищення до рівня університету Києво-Могилянського колегіуму, але й створення ще одного такого ж закладу в іншому українському місті. 3 огляду на важливу роль Львова у господарчому, суспільному і релігійно-культурному житті України, а також - зважаючи на давні традиції православного шкільництва у цьому місті, воно цілком підходило як вірогідне місце розташування другої православної академії.

Абстрагуючись від питання, наскільки реалістичними були в той час перспективи Гадяцької унії (вже після відставки Івана Виговського і фактичного розколу України на дві частини), варто відзначити, що єзуїти вміло скористалися з цього, аби реалізувати свою мету. Мотив створення фортеці католицизму на бунтівних східних antemurales christianitas був надзвичайно затребуваний у розбурханому (в т. ч. 3 конфесійної точки зору) морі Речі Посполитої, яка щойно пройшла через досвід Хмельниччини і Потопу. На думку єзуїтів, це мало нейтралізувати потенційні інтриги Краківської академії, спрямовані на те, аби не допустити створення нового університету (як це вже було свого часу у Познані в 1611-1615 pp. $)^{27}$. Не випадково у вищезгаданій пропозиції Конгрегації Польської провінції, ухваленій 8 жовтня 1660 р., особливо наголошувалося на тому, що ця справа $\epsilon$ терміновою і іiі треба залагодити до того моменту, коли про ініціативу єзуїтів дізнаються їх вороги. Тобто, йшлося про такий собі бліц-кріг, прагнення використати сприятливу суспільну атмосферу, поки свіжіші антипротестантські й антиправославні настрої витіснили зі свідомості польської католицької шляхти старі антиєзуїтські меседжі. Оперативність дій в цій ситуації мала позбавити Краківську академію можливості розігнати нову антиєзуїтську хвилю серед шляхетської громадськості. 
Отже, простежимо хронологію подій. 8 жовтня 1660 р. Конгрегація Польської провінції (у Домі пробацій при костьолі св. Стефана, в Кракові) звернулася до генерала ордена із проханням підтримати ії ініціативу щодо створення у Львові університету. Своє рішення єзуїти мотивували, втім, не лише примарою православної академії. Вони озвучили ще два потужні меседжі. По-перше, було наголошено на тому, що Польська провінція ордену потребує свого власного університету, який би став вінцем іï шкільної системи ${ }^{28}$. Питання це було аж ніяк не новим й актуалізувалося вже з перших років існування цієї адміністративної одиниці ордену власне в такому територіальному форматі (з 1608 р.). Причини, чому це питання час від часу піднімалося, є очевидними - 3 припиненням у першій чверті XVII ст. активної транскордонної міграції єзуїтів ${ }^{29}$ провінція дедалі сильніше відчувала брак кваліфікованих кадрів, підготовку яких - включно із наданням наукових ступенів - й могла забезпечити власна академія (як це робила Віленська академія в Литовській провінції). Другим важливим моментом $є$ підкреслення особливого статусу Львова. В Постулатах Конгрегації наголошувалося на тому, що він $є$ столицею Pусі (Metropolis Russiae), потужним осередком церковного і державного життя, а саме - резиденцією католицького i вірменського архієпископів, православного єпископа та світських сенаторів (saecularium Senatorum) римо-католицького віросповідання, а також $є$ відомий освіченістю своїх мешканців (civium doctrina) й іншими достоїнствами ${ }^{30}$.

Ці панегіричні пасажі слугують відголоском апеляції єзуїтів до місцевого патріотизму шляхти Руського воєводства, на чому певно й робився наголос в процесі залучення на свій бік представників місцевої еліти. Саме такі мотиви створення Львівської академії прослідковуються у п. 52 інструкцій, які надав своїм послам сеймик Руського воєводства у Вишні 23 лютого 1662 р. Згадуючи про те, що Краківське воєводство має свою академію, руська шляхта не розуміє, чому вона не заслуговує того ж самого і повинна відправляти своїх дітей на навчання у віддалений Краків ${ }^{31}$. Ідею Львівської академії також частково підтримало місцеве міщанство. У цьому пересвідчує клопотання львівського магістрату і ради перед канцлером о. Міколаєм Пражмовським про необхідність, аби “у Львові стала нова Академія”. Головним лобістом ухвалення цього рішення був бурмістр Львова Марцін Анчовський ${ }^{32}$.

Навіть не чекаючи розгляду цього питання на Генеральній конгрегації Товариства Iсуса, єзуїти Польської провінції - за сприяння канцлера о. Міколая Пражмовського - домоглися королівської санкції на створення Львівської академії. 20 січня 1661 р. Ян Казимир видав диплом, згідно з яким Львівський колегіум отримував всі права, аналогічні тим, котрі мали Краківська і Віленська академії. В ньому дозволялося викладати теологію (схоластичну і моральну), філософію, математику, канонічне і цивільне право, медицину, вільні мистецтва, а також "всі науки і мистецтва, яких отці Товариства Ісуса будуть вважати за необхідне навчати самі або за допомоги інших, згідно з власною думкою і постановою, згідно із звичаєм і практикою Академії і Університетів”. Окремо зазначалося, що Львівська академія має право надавати академічні ступені і всі інші промоції й урочистості, які вживаються в університетах. О. Міколай Пражмовський завірив фундаційний диплом великою коронною печаткою, а о. Анджей Сікорський - придворний теолог канцлера - облятував цей документ до Коронної Метрики ${ }^{33}$.

Рішення самого монарха у подібній справі було втім недостатньо, воно мало бути схваленим Сеймом - головним інститутом влади у Речі Посполитій. Саме за такою процедурою набувала юридичної сили Гадяцька угода (включно із статтею, яка санкціонувала відкриття православної академії в Києві і ще деінде в Україні). ІЇї текст увійшов до Сеймової конституції 1659 p. $^{34}$. Був щоправда інший шлях легітимізації університету. За традицією, започаткованою ще у добу Середньовіччя, це міг зробити не лише монарх, але й римський папа. I скажімо у випадку Віленської академії видання відповідного королівського привілею (а точніше двох - 7 липня 1578 р. і 1 квітня 1579 р.) було зміцнено буллою Григорія XIII (30 жовтня 1579 р.) $)^{35}$. В єзуїтському середовищі і при дворі Яна Казимира цей шлях трактувався як порівняно легший (з огляду на можливу протидію в Сеймі з боку лобістів Краківської академії - як воно власне й сталося згодом). Саме тому вже 15 травня $1661 \mathrm{p}$. Ян Казимир пише листа до папи із проханням затвердити його фундаційний диплом для Львівської академії. При цьому знову акцентується на важливому значенні цього кроку 3 точки зору зміцнення позицій католицизму на сході Речі Посполитої ${ }^{36}$. 
Проте в Римі справи не пішли належним чином. У цьому опосередковано пересвідчує брак оперативної реакції генерала ордена на Постулати Конгрегації Польської провінції 1660 р. Адже озвучити чітке позитивне рішення у справі Львівської академії голова Товариства Ісуса міг, лише отримавши підтримку від папи (про потребу заручитися сприятливою опінією римського понтифіка недвозначно говориться у самих Постулатах). Відповідь на Постулати з'явилася лише через рік (24 грудня 1661 р.), коли справу вже фактично було вирішено. І ця відповідь мала недвозначний характер - “треба добре звернути увагу на такі слова: в умовах, коли не припиняється [пошук] способу зміцнення статусу, було наказано [шукати] інший спосіб, який тільки є можливим. Щодо власне самого шляху виконання, то від Його Найсвятішості пропонується нині передати - нам не личить взагалі будь-щз здійснювати без волі на те найвищої влади"з7. Отже, Рим не наважився взяти на себе відповідальність за легітимізацію Львівської академії, залишивши цю справу цілком на відкуп політичній еліті Речі Посполитої.

Схвалення Сеймом королівського рішення про перетворення Львівської школи ордену в університет виявилося неможливим внаслідок активної протидії Краківської академії. На той момент ії давній антагонізм із Товариством Ісуса вже пройшов кілька фаз активної боротьби (остання чверть XVI ст., 1610-і pp., 1623-1634 pp., 1650 p.), ареною якої виступав не тільки сам Краків, але й інші міста Речі Посполитої. І якщо університетським амбіціям віленських єзуїтів Краківська академія чинила кволий опір 38 , то у Познані вона дала рішучий бій Товариству Ісуса. Перебіг цієї історії є напрочуд схожим на події 1660-х рр. у Львові. В 1611 р. Конгрегація Польської провінції ордену ініціювала створення Познанської академії. 28 жовтня того ж року Сигізмунд III видав привілей, який дозволяв Познанському колегіуму надавати наукові ступені. Краківська академія опротестувала це рішення (12 травня 1612 р.), розпочавши водночас активно лобіювати свою позицію при королівському дворі, в Сеймі і папській курії. Зрештою станово-представницький орган влади Речі Посполитої 29 березня 1613 р. видав маніфест, який проголошував нелегітимною раніше відкриту єзуїтську академію в Познані ${ }^{39}$. Своєю чергою Рим зайняв в цьому конфлікті таку ж саму вичікувальну позицію, як і щодо Львівської академії півстоліттям пізніше. Він очікував рішення Варшави, а саме - короля Сигізмунда III. В 1615 р. Конгрегація Польської провінції - на свій постулат про потребу клопотати перед папою щодо затвердження Познанської академії - отримала від генерала Мутіуса Віттелескі таку промовисту відповідь - "За нинішньої ситуаиії, якщо позиція короля залишається саме такою, якою вона є відомою папі на підставі надісланої йому інформачії, ми не можемо аж ніяк розглядати ию справу в Його Святішості. Коли ж однак Король Його Милість виявить Його Святішості свою чітку прихильність до Товариства Ісуса, тоді ми будемо всіляко підтримувати ию справу" ". Нерішучість Сигізмунда III врешті-решт визначила поразку єзуїтів: Павло IV під впливом Якуба Янідла (повноважного представника Краківської академії) визнав слушність аргументів найдавнішого польського університету ${ }^{41}$.

Але повернемося до справи Львівської академії. Напередодні початку Сейму 1661 p. обидві сторони конфлікту (Краківська академія і єзуїти) розгорнули активну агітаційнопубліцистичну компанію, покликану схилити на свій бік голоси послів. Зокрема, вищезгаданий о. Анджей Сікорський написав брошуру “Rationes quod non tantum expediat, sed etiam necesse sit Academiam Leopoli in Collegio Patribus Societatis Iesu erigere" ("Причини, з яких не тільки необхідно, але й треба заснувати академію у Львові, в Колегіумі Товариства Icyca”). В ній містилися стандартні аргументи, про які йшлося вище: це необхідно для блага віри і католицької церкви, яка веде боротьбу зі схизматиками і єретиками. Наділення Львівського осередку статусом академії (в т. ч. правом надавати ступінь доктора теологіi) забезпечить місцевий клір фахівцями, здатними давати гідну ідеологічну відсіч докторам-схизматикам.

Але водночас з'являються й цікаві зауваження, вістря яких безпосередньо було спрямоване проти Краківської академії. Так, скажімо, вищезгаданий меседж про Гадяцьку угоду і дві православні академії набуває цілком нового звучання, коли о. Анджей Сiкорський задається питанням, чому ж Краківська академія не протестувала проти цих нововведень. Ще цікавішим є п. 5, в якому зазначається, що оскільки Польща і ВКЛ мають свої католицькі академії, то чому цього має бути позбавлена Русь? Автор також 
не гребує тим, аби розглянути це питання у загальноєвропейському контексті. Зокрема, він запитує: чому в тій же Італії жоден університет не має освітньої монополії (на кшталт тієї, на яку претендує Краківська академія) і там мирно співіснують Падуанська і Болонська академії? ${ }^{42}$.

Краківська академія також не втрачала часу. ІІї представники надрукували і поширили серед учасників сейму 1661 р. своє бачення недоцільності створення у Львові університету ${ }^{43}$. Найбільший резонанс 3 контраргументів Краківської академії викликала заява про нелегітимний характер диплома Яна Казимира, який нібито було ініційоване лише частиною райців львівського магістрату без відома ради, але від її імені. Львівський райця Себастьян Краус підтвердив цю інформацію. 3 огляду на суперечливість справи, iї вирішили відкласти до наступного сейму. Як виявилося згодом, ця подія мала переломний характер. У міжсеймовий період до гроду варшавського було внесено низку протестацій проти створення у Львові єзуїтського університету ${ }^{44}$. Окрім того, Краківській академії вдалося схилити на свій бік магістрат і капітулу Львова, а також майже всіх римо-католицьких єпископів (за винятком о. Міколая Пражмовського, о. Анджея Тшебіцького, о. Станіслава Сарновського i о. Томаша Уєйського). Негативне ставлення громадськості Речі Посполитої до ідеї створення у Львові академії знайшло закономірний підсумок у рішенні сейму 1662 р., який відмовився схвалити диплом Яна Казимира ${ }^{45}$.

Попри невдачу у Варшаві і недвозначне ставлення до цієї справи у Римі, єзуїти спробували переконати папу, аби той схвалив диплом Яна Казимира. 3 цією метою вони направили до Риму меморіал з обгрунтуванням необхідності відкриття у Львові єзуїтської академії, а також проханням підтримати їх наміри. Попри те, що останній документ був підписаний лише низкою прихильників ордену з-поміж соціальної еліти Речі Посполитої, він був представлений як волевиявлення всієї держави. Очевидне за таких умов шахрайство викликало різку реакцію в середовищі місцевої панівної верстви. В результаті, від імені шляхетського стану та Краківської академії було складено контрмеморіал, в якому обгрунтовувалась недоцільність затвердження папою Олександром VII диплома Яна Казиміра. Після того, як цей документ надійшов до Риму, понтифік санкціонував вивчення змісту обох меморіалів спеціальною комісією у складі чотирьох кардиналів і двох прелатів. Вони, втім, виявилися неспроможними дійти певного висновку у справі Львівської академії і вимушені були звернутися за консультацією до апостольського нунція у Польщі. Останній підтвердив, що надання Львівському колегіуму статусу університету є нелегітимним без згоди сейму Речі Посполитої. Вердикт нунція поклав край коливанням Олександра VII, який відмовився схвалити диплом Яна Казиміра ${ }^{46}$.

Отже, вищезгадані факти виразно свідчать, що з правової точки зору Львівська єзуїтська школа після 1661 р. залишалася лише середнім навчальним закладом. Щодо фактичного стану речей, то тут спостерігається неоднозначна ситуація. Спочатку ми бачимо швидке розширення кола теологічних дисциплін. Ще напередодні появи диплома Яна Казимира (а саме восени 1660 р.) у Львові починається викладання контроверсійної теології, наступного навчального року з'являються курси схоластичної і позитивної теології, а 1662/63 н. p. - екзегези Св. Письма ${ }^{47}$. Проте крах сподівань на легітимізацію Львівської академії призвів до швидкого звуження цього формату теологічних дисциплін. Скажімо, позитивна теологія читалася тут лише три навчальні роки - в 1661/62, 1663/64, 1664/65, екзегеза Св. Письма - тільки в 1662/63 н. р., а контроверсійна теологія - до 1668/69 н. р. включно ${ }^{48}$ В результаті, залишилися самі тільки схоластична і моральна теологія, чого було звісно замало для того, аби претендувати на статус академії із теологічним факультетом. Лише десятиліттям пізніше львівські єзуїти знову спробували реалізувати свою мрію. Восени 1679 р. у Львівському осідку ордену розпочинається викладання курсів позитивної і контроверсійної теології, а також - гебрайської мови. Якщо остання так і залишилася однорічним експериментом, то дві інші теологічні дисципліни аж до кінця XVII ст. читалися - за винятком кількох н. р. - щорічно ${ }^{49}$.

Наскільки тодішній рівень добробуту Львівського колегіуму відповідав його університетським амбіціям? Важливий крок в цьому напрямку було зроблено у листопаді $1661 \mathrm{p}$. (а конкретніше - в першу суботу після дня Всіх Святих), коли єзуїт Павел Пясечинський пожертвував Львівському колегіуму 30000 злотих ${ }^{50} .3$ огляду на час іiї надання та особу жертводавця, не підлягає сумніву, що ці кошти були передбачені саме на створення акаде- 
мії. Вони, втім, так і не конвертувалися у міцне підгрунтя для ведення освітньої діяльності (у формі нових маєтків чи сум капіталів). Адже тодішні щорічні прибутки Львівського колегіуму у 1665 р. та 1669 р. залишилися на звичному для нього рівні, а у 1672 р. навіть зазнали скорочення ${ }^{51}$. В цьому зв'язку виглядає доцільним припустити, що значна частина отриманої фундаційної суми була витрачена на технічний бік трансформації Львівської єзуїтської школи та наступні заходи щодо легітимізації ії̈ університетського статусу. Разом $з$ тим, потрібні в цій ситуації нові пожертвування на користь Львівського колегіуму мали порівняно незначні обсяги (відповідно 6000 та 500 фл. у 1666 та 1668 рр.) ${ }^{52}$. Отже, Львівський осередок ордену не мав економічних можливостей для тривалого збереження структури освіти своєї школи на рівні, створеному у 1661-1663 pp.

Таким чином, аналіз розвитку Львівської єзуїтської школи в 1608-1648 р. не підтверджує тезу Л. Фінкеля про те, що вона вже тоді послідовно готувалася до набуття академічного статусу. За рівнем свого матеріального забезпечення і структурою навчальної діяльності Львівський колегіум належав до середняків Польської провінції, а Познанський, Калішський і Люблінський осідки ордену мали кращі стартові умови у боротьбі за університетський статус. Отже, історія Львівської академії 1661 р. була інспірована радше мінливою кон'юнктурою тодішнього суспільно-політичного життя. Перетворення Львова на класичний взірець antemurales christianitas, Гадяцька унія і примара появи на цих “кресах" православного університету - все це дало єзуїтам зручну нагоду вміло зіграти на релігійних почуттях католицької шляхти, які вкрай загострилися під час агресії протестантських держав (Швеції, Бранденбургу і Трансільванії) і збройного протистояння із православним Сходом (козаками і московітами). Однак старі стереотипи про орден часів його активного протистояння із Краківською академією виявилися вкрай живучими, не дозволивши зрештою довести процес освітньої трансформації Львівського колегіуму до логічного кінця. В результаті, навіть попри появу фундаційного диплому Яна Казимира, справа була програна - і Сейм, і римська курія відмовили Львівській академії у легітимному статусі. Реальний стан речей також не відповідав університетським амбіціям львівських єзуїтів - від майже повного циклу теологічних дисциплін до кінця 1660-х рр. залишилися тільки курси схоластичної і моральної теології. І лише десятиліттям пізніше починають здійснюватися реальні спроби надолужити втрачене. Ця структурна деструкція пояснюється тим, що університетські мрії львівських єзуїтів не мали належного матеріального підгрунтя - фундація Павла Пясечинського виявилася поодиноким епізодом, а самі кошти не перетворилися на стале джерело прибутків. Відтак львівські єзуїти вимушені були тимчасово відступитися своїх намірів, повернувшись до їх реалізації вже у добу Августа III.

${ }^{1}$ Історія Університету [Електронний ресурс]. - Режим доступу: http://www.lnu.edu.ua/about/university-today-and-tomorrow/history/.

2 Див., зокрема: Bielski J. Widok Krolestwa Polskiego ze wszystkimi woiewodztwami, xięstwy y ziemiami, monarchami z monarchiniami. T. 1. Poznan, 1763.

${ }^{3}$ Фелікс Бентковський згадує про спробу створення єзуїтської академії у Львові (1661р.), але при цьому не називає дату цієї події. Bentkowski F. Historia literatury polskiej. Т. 1. Warszawa-Wilno, 1814. S. 149.

${ }^{4}$ Chodynicki I. Historya stołecznego Królestw Galicyi i Lodomeryi miasta Lwowa od założenia jego aż do czasów teraznieyszych. Lwów, 1829. S. 401-403.

${ }^{5}$ Łukaszewicz J. Historya szkół w Koronie i w Wielkiem Księstwie Litewskiem od najdawniejszych czasów aż do roku 1794. T. 1. Poznań, 1849. S. 158.

${ }^{6}$ Ibidem. S. 158-167; Krzyżanowski A. Dawna Polska ze stanowiska jej udziału w dziejach postępującej ludzkości skreślona w jubileuszowym Mikołaja Kopernika roku 1843. Warszawa, 1844. S. 179.

${ }^{7}$ Łukaszewicz J. Historya szkół w Koronie i w Wielkiem Księstwie Litewskiem od najdawniejszych czasów aż do roku 1794. T. 1. Poznań, 1849. S. 167-169.

${ }^{8}$ Finkel L., Starzyński S. Historya Uniwersytetu Lwowskiego. Cz. I. Lwów, 1894; Załęski S. Jezuici w Polsce. T. 3. Lwów, 1902; Jaworski F. Uniwersyt Lwowski. Wspomnienia jubileuszowe. Lwów, 1912; Finkel L. Króla Jana Kazimierza dyplom erekcyjny Uniwersytetu Lwówskiego z r. 1661 // Księga Pamiątkowa ku uczczeniu 250-tej rocznicy założenia Uniwersytetu Lwówskiego przez króla Jana Kazimierza r. 1661. T. 1. Lwów, 1912. S. 1-20. Пор.: Вінковский Т. Йосиф чи Ян Казимір (з нагоди святкування мнимої 250-літної річниці єствованя Львівського Університету). Львів: Руслана, 1912. 
${ }^{9}$ Zatęski S. Jezuici w Polsce. T. 3. Lwów, 1902. S. 146-151.

${ }^{10}$ Finkel L. Króla Jana Kazimierza dyplom erekcyjny Uniwersytetu Lwówskiego z r. 1661 // Księga Pamiątkowa ku uczczeniu 250-tej rocznicy założenia Uniwersytetu Lwówskiego przez króla Jana Kazimierza r. 1661. T. 1. Lwów, 1912. S. 7-11.

${ }^{11}$ Ibidem. S. 19.

${ }^{12}$ Kot S. Historia wychowania. Zarys podręcznikowy. T. 2. Lwów, 1934. S. 219.

${ }^{13}$ Podhorodecki L. Dzieje Lwowa. Warszawa, 1993. S. 8; Kaczorowski B. Zabytki starego Lwowa. Warszawa, 1990. S. 11, 120. Encyklopedia wiedzy o jezuitach na ziemiach Polski i Litwy. 1564-1995. Kraków, 1996.

${ }^{14}$ Лазаренко Є. К. 300 років Львівського університету. Львів, 1961. С. 7; Історія Львова / за ред. В. В. Секретарюка. Київ: Наукова думка, 1984. С. 74.

${ }^{15}$ Encyklopedia wiedzy o jezuitach na ziemiach Polski i Litwy. 1564-1995. Kraków, 1996. S. 379.

${ }^{16}$ Archivum Romanum Societatis Iesu (далі-ARSI). Polonica 12. F. 138, 148.

17 Див., зокрема: Encyklopedia wiedzy o jezuitach na ziemiach Polski i Litwy. 1564-1995. Kraków, 1996. S. $261,320,373-374,534-535$.

${ }^{18}$ Ibidem. S. 379.

${ }^{19}$ Скажімо, в Луцькій єзуїтській школі в 1609 р. навчалося 150 , а в 1616 р. - 300 учнів. Своєю чергою в Кам'янець-Подільському колегіумі в 1611 і 1626 рр. було відповідно 180 і трохи більше за 100 вихованців. Natoński B. Szkolnictwo jezuickie w Polsce w dobie kontrreformacji // Z dziejów szkolnictwa jezuickiego w Polsce. Kraków, 1994. S. 48-49.

${ }^{20}$ Encyklopedia wiedzy o jezuitach na ziemiach Polski i Litwy. 1564-1995. Kraków, 1996. S. 535.

${ }^{21}$ ARSI. Polonica 12. F. 148, 140, 129, 125, 137, 135.

${ }^{22}$ ARSI. Polonica 11. F. 200, 204.

${ }^{23}$ ARSI. Polonica 12. F. 135, 297-297v.; ARSI. Polonica 13. F. 131-131v.

${ }^{24}$ Piechnik L. Dzieje Akademii Wileńskiej. T. 2. Rzym, 1983. S. 125-156.

${ }^{25}$ ARSI. Polonica 13. F. 131, 203; ARSI. Polonica 14. F. 109.

${ }^{26}$ Львівська національна наукова бібліотека України імені Василя Стефаника (далі- ЛННБУ імені В.Стефаника). Відділ рукописів. Ф. Баворовських. Спр. 997/II. Арк. 50зв.-51.

${ }^{27}$ Natoński B. Jezuici a Uniwersytet Krakowski w XVI wieku. Kraków, 2002. S. 113-114; Encyklopedia wiedzy o jezuitach na ziemiach Polski i Litwy. 1564-1995. Kraków, 1996. S. 535.

28 ЛННБУ імені В.Стефаника. Відділ рукописів. Ф. Баворовських. Спр. 997/II. Арк. 50 зв.-51.

${ }^{29}$ Див., зокрема: Natoński B. Szkolnictwo jezuickie w Polsce w dobie kontrreformacji // Z dziejów szkolnictwa jezuickiego w Polsce. Kraków, 1994. S. 37-39.

30 ЛННБУ імені В.Стефаника. Відділ рукописів. Ф. Баворовських. Спр. 997/II. Арк. 50 зв.-51.

${ }^{31}$ Akta grodzkie i ziemskie z czasów Rzeczypospolitej Polskiej z archiwum tak zwanego bernardyńskiego we Lwowie. T. XXI. Lwów, 1911. S. 344.

32 Л. Фінкель стверджував, що саме Марцін Анчовський разом із дружиною подарував львівським єзуїтам в цілях матеріального забезпечення майбутньої Академії 30000 злотих. Finkel L. Króla Jana Kazimierza dyplom erekcyjny Uniwersytetu Lwówskiego z r. 1661 // Księga Pamiątkowa ku uczczeniu 250-tej rocznicy założenia Uniwersytetu Lwówskiego przez króla Jana Kazimierza r. 1661. T. 1. Lwów, 1912. S. 18.

${ }^{33}$ Ibidem. S. 9-10.

${ }^{34}$ Volumina legum. T. 4. Petersburg, 1860. S. 298.

${ }^{35}$ Piechnik L. Dzieje Akademii Wileńskiej. T. 1. Rzym, 1984. S. 56-60.

${ }^{36}$ Zatęski S. Jezuici w Polsce. T. 3. Lwów, 1902. S. 152.

${ }^{37}$ ЛННБУ імені В. Стефаника. Відділ рукописів. Ф. Баворовських. Спр. 997/II. Арк. 60.

${ }_{38}$ Вона спробувала позбавити Віленську академію права надавати наукові ступені 3 права і медицини. Див.: Piechnik L. Dzieje Akademii Wileńskiej. T. 1. Rzym, 1984. S. 58.

${ }^{39}$ Encyklopedia wiedzy o jezuitach na ziemiach Polski i Litwy. 1564-1995. Kraków, 1996. S. 535; Krzyżanowski A. Dawna Polska ze stanowiska jej udziału w dziejach postępującej ludzkości skreślona w jubileuszowym Mikołaja Kopernika roku 1843. Warszawa, 1844. S. 142.

${ }^{40}$ Цит. по: Natoński B. Jezuici a Uniwersytet Krakowski w XVI wieku. Kraków, 2002. S. 113.

${ }^{41}$ Krzyżanowski A. Dawna Polska ze stanowiska jej udziału w dziejach postępującej ludzkości skreślona w jubileuszowym Mikołaja Kopernika roku 1843. Warszawa, 1844. S. 142.

${ }_{42}$ Biblioteka Jagiellońska w Krakowie. Rkps 5. F. 772-773.

${ }^{43}$ Eukaszewicz J. Historya szkół w Koronie i w Wielkiem Księstwie Litewskiem od najdawniejszych czasów aż do roku 1794. T. 1. Poznań, 1849. S. 159-160.

${ }^{44}$ Йдеться про: 1) протестацію Анджея Потоцького, Владислава Любовецького, Габріеля Сільніцького і Пьотра Хжонстовського - послів від Краківського воєводства та Галицької землі (18 липня 1661 р.); 2) протестацію від імені всього Краківського воєводства (19 жовтня 1661 р.); 3) протестацію львівської капітули (22 вересня 1661 р.). Див.: Załęski S. Jezuici w Polsce. T. 3. Lwów, 1902. S. 150; Łukaszewicz J. Historya szkół w Koronie i w Wielkiem Księstwie Litewskiem od najdawniejszych czasów aż do roku 1794. T. 1. Poznań, 1849. S. 160-161. 
${ }^{45}$ Zatęski S. Jezuici w Polsce. T. 3. Lwów, 1902. S. 148-149; Вінковский T. Йосиф чи Ян Казимір (з нагоди святкування мнимої 250-літної річниці єствованя Львівського Університету). Львів: Руслана, 1912. С. 8.

${ }^{46}$ Eukaszewicz $J$. Historya szkół w Koronie i w Wielkiem Księstwie Litewskiem od najdawniejszych czasów aż do roku 1794. T. 1. Poznań, 1849. S. 162, 167; Zatęski S. Jezuici w Polsce. T.3. Lwów, 1902. S. 152-153; Барвінський Б. Предтеча університету ім. Франца I у Львові // Записки НТШ. 1918. T. CXXV. C. 5.

${ }^{47}$ ARSI. Polonica 14. F. 109, 265.

${ }^{48}$ ARSI. Polonica 14. F. 265; ARSI. Polonica 15. F. 118, 207.

${ }^{49}$ ARSI. Polonica 18. F. 136; ARSI. Polonica 20. F. 172-172v., 356; ARSI. Polonica 21A. F. 16; ARSI. Polonica 22. F. 156; ARSI. Polonica 19. F. 42; ARSI. Polonica 20. F. 56; ARSI. Polonica 44. F. 347v., 356; ARSI. Polonica 18. F. 46v.; ARSI. Polonica 19. F. 66v.; ARSI. Polonica 44. F. 328v.

${ }^{50}$ Biblioteka PAU w Krakowie. Rkps 881. F. 2v.

${ }^{51}$ ARSI. Polonica 14. F. 265; ARSI. Polonica 15. F. 118, 207v.

${ }^{52}$ Biblioteka PAU w Krakowie. Rkps 881. F. 2v. 